\title{
Pemodelan Persentase Peserta KB Aktif Metode Kontrasepsi Jangka Panjang (MKJP) di Provinsi Jawa Timur Menggunakan Regresi Nonparametrik Spline Truncated
}

\author{
Novalia Dwita Pramitasari dan I Nyoman Budiantara \\ Departemen Statistika, Fakultas Matematika, Komputasi, dan Sains Data \\ Institut Teknologi Sepuluh Nopember (ITS) \\ e-mail: i_nyoman_b@statistika.its.ac.id
}

\begin{abstract}
Abstrak-Pemakaian Metode Kontrasepsi Jangka Panjang (MKJP) pada peserta KB aktif di Provinsi Jawa Timur sebagai cara mengatur kehamilan sebanyak 1,75 juta jiwa lebih rendah dibandingkan dengan pemakaian non-MKJP yang mencapai 4,35 juta jiwa. MKJP merupakan alat/cara kontrasepsi yang efektif dan efisien dipakai dalam jangka waktu lama untuk tujuan menjarangkan kehamilan atau mengakhiri kehamilan pada pasangan yang sudah tidak ingin menambah anak lagi. Sedangkan peserta KB aktif merupakan akseptor Pasangan Usia Subur (PUS) usia 15-49 tahun yang saat ini sedang menggunakan salah satu alat/cara kontrasepsi. Faktor-faktor yang diduga berpengaruh tidak membentuk suatu pola tertentu, sehingga menggunakan metode regresi nonparametrik spline truncated. Model terbaik diperoleh dari titik knot optimum berdasarkan nilai Generalized Cross Validation (GCV) minimum. Lima variabel yang berpengaruh signifikan yaitu persentase perempuan usia 15-49 tahun berstatus kawin memiliki anak masih hidup lebih dari dua, persentase perempuan usia 35 tahun keatas berstatus kawin, persentase perempuan usia 15-49 tahun berstatus kawin pernah menggunakan alat/cara $\mathrm{KB}$, persentase perempuan usia 15-49 tahun berstatus kawin yang bekerja, dan persentase perempuan usia 15 tahun keatas berstatus kawin dengan usia kawin pertama kurang dari 19 tahun. Pemodelan terbaik dengan GCV paling minimum pada tiga titik knot atau kombinasi titik knot $(3,3,3,3,3)$ sebesar 31,91. Nilai $R^{2}$ yang dihasilkan model sebesar $90,69 \%$.
\end{abstract}

Kata Kunci-Generalized Cross Validation, Metode Kontrasepsi Jangka Panjang, Peserta KB Aktif, Regresi Nonparametrik Spline Truncated, Titik Knot

\section{PENDAHULUAN}

$\mathrm{K}$ EBERHASILAN pembangunan tidak hanya mencakup pada meningkatnya perekonomian dan pembangunan fisik, akan tetapi juga pada pembangunan manusia di suatu negara. Pembangunan manusia saat ini menjadi tujuan dalam model pembangunan di Indonesia, salah satunya pembangunan kependudukan dan keluarga berencana. Hal tersebut sesuai dengan Rencana Pembangunan Jangka Menengah Nasional (RPJMN) tahun 2015-2019 dalam Agenda Prioritas Pembangunan (Nawacita) terutama nomor 5 (lima), yaitu "Meningkatkan Kualitas Hidup Manusia dan Masyarakat Indonesia" melalui "Pembangunan Kependudukan dan Keluarga Berencana" [1]. Sasaran pokok pembangunan KKB adalah menurunnya rata-rata laju pertumbuhan penduduk dan Total Fertility Rate (TFR), serta meningkatnya Contraceptive Prevalence Rate (CPR). Indonesia sebagai negara peringkat ke-4 dengan jumlah penduduk tertinggi di dunia pada tahun 2016 memerlukan pencapaian sasaran pokok tersebut sebagai upaya menekan jumlah penduduk sehingga mobilitas penduduk lebih terarahkan dalam mewujudkan masyarakat tumbuh seimbang yaitu melalui program Keluarga Berencana (KB).

Jawa Timur merupakan salah satu provinsi di Indonesia dengan jumlah penduduk tertinggi kedua setelah Provinsi Jawa Barat yaitu pada tahun 2016 sebesar 39,08 juta jiwa. Sejalan dengan semakin meningkatnya jumlah penduduk tersebut, CPR di Provinsi Jawa Timur justru menurun dari tahun 2015 sebesar 76,64\% (6,30 juta peserta KB aktif dari 8,22 juta PUS) menjadi $75,78 \%$ (6,10 juta peserta KB aktif dari 8,05 juta PUS) tahun 2016 [2]. Sulitnya meningkatkan CPR disebabkan karena masih tingginya kekhawatiran PUS terhadap efek samping pemakaian alat/cara kontrasepsi.

Upaya dalam rangka mempercepat pengendalian fertilitas dan mengurangi kegagalan KB yaitu melalui pemakaian kontrasepsi yang lebih diarahkan pada Metode Kontrasepsi Jangka Panjang (MKJP) pada peserta KB aktif. MKJP pada peserta KB aktif di Provinsi Jawa Timur sebagai cara mengatur kehamilan pada tahun 2016 sebanyak 1,75 juta jiwa lebih rendah dibandingkan pemakaian non-MKJP yang mencapai 4,35 juta jiwa. MKJP adalah alat/cara kontrasepsi yang dapat dipakai dalam jangka waktu lama, lebih dari dua tahun, efektif, dan efisien untuk tujuan pemakaian menjarangkan kelahiran lebih dari tiga tahun atau mengakhiri kehamilan pada pasangan yang sudah tidak ingin menambah anak lagi [3]. Jenis alat/cara yang termasuk dalam MKJP diantaranya IUD (Intra Uterine Device), MOW (Metode Operasional Wanita), MOP (Metode Operasional Pria), dan Implant/Susuk.

Pada penelitian ini dilakukan pemodelan menggunakan regresi linier berganda terlebih dahulu. Hal ini untuk membuktikan bahwa regresi nonparametrik spline truncated lebih tepat digunakan daripada regresi linier berganda. Berdasarkan pola data pada variabel prediktor terhadap variabel respon tidak mengikuti suatu pola tertentu sehingga pemodelan menggunakan metode regresi nonparametrik spline truncated. Regresi nonparametrik menghasilkan model yang memiliki interpretasi statistik dan interpretasi visual serta memiliki kemampuan yang sangat baik untuk digeneralisasikan pada pemodelan statistika yang kompleks dan rumit [4]. Salah satu pendekatan dalam regresi nonparametrik adalah pendekatan regresi nonparametrik spline. Spline mampu menangani karakter data yang bersifat mulus (smooth) [5]. Variabel-variabel yang digunakan berdasarkan penelitian terdahulu yaitu meliputi persentase perempuan usia 15-49 tahun berstatus kawin memiliki anak masih hidup lebih dari dua, persentase perempuan usia 1549 tahun berstatus kawin dengan pendidikan tertinggi yang 
ditamatkan minimal SMP sederajat, persentase perempuan usia 35 tahun keatas ber-status kawin, persentase perempuan usia 15-49 tahun ber-status kawin pernah menggunakan alat/cara KB, persentase perempuan usia 15-49 tahun berstatus kawin yang bekerja, dan persentase usia kawin pertama kurang dari 19 tahun.

\section{TINJAUAN PUSTAKA}

\section{A. Regresi Linier Berganda}

Regresi linier berganda merupakan metode yang memodelkan hubungan antara variabel respon (y) dan variabel prediktor $\left(x_{1}, x_{2}, \ldots, x_{p}\right)$. Model regresi linier untuk $p$ variabel prediktor secara umum ditulis sebagai berikut [6].

$$
y_{i}=\beta_{0}+\sum_{k=1}^{p} \beta_{k} X_{i k}+\varepsilon_{i}
$$

dengan

$y_{i}$ : observasi variabel respon pada pengamatan ke- $i$,

$i=1,2, \ldots, n$

$x_{i k}$ : observasi variabel prediktor ke- $k$ pada pengamatan ke- $i$

$\beta_{0}$ : intersep dalam model regresi

$\beta_{k}$ : koefisien regresi untuk variabel prediktor ke- $k$,

$k=1,2, . ., p$

$\varepsilon_{i} \quad$ : error ke- $i\left(\varepsilon_{i} \square \operatorname{IIDN}\left(0, \sigma^{2}\right)\right)$

Pendugaan parameter model regresi linier diperoleh menggunakan metode Ordinary Least Square (OLS) dengan meminimumkan jumlah kuadrat error diperoleh persamaan sebagai berikut [7]

$$
\hat{\beta}=\left(\mathbf{X}^{\mathrm{T}} \mathbf{X}\right)^{-1} \mathbf{X}^{\mathrm{T}} \underline{\boldsymbol{y}}
$$

dengan

$\underset{\sim}{\boldsymbol{y}}:$ vektor variabel respon

$\mathbf{X}$ : matriks variabel prediktor

$\hat{\boldsymbol{\beta}}$ : vektor parameter dalam model regresi

\section{B. Regresi Nonparametrik Spline Truncated}

Regresi nonparametrik spline truncated merupakan suatu regresi yang memiliki kurva regresi dirancang dengan cara modifikasi fungsi polinomial [8]. Salah satu model regresi nonparametrik yang memiliki interpretasi statistik dan visual sangat khusus dan sangat baik yaitu spline [9]. Dalam analisis regresi nonparametrik spline truncated, apabila terdapat satu variabel respon dan satu variabel prediktor maka disebut regresi nonparametrik spline truncated univariabel. Sedangkan jika terdapat satu variabel respon dengan lebih dari satu variabel prediktor maka dinamakan regresi nonparametrik spline truncated multivariabel [10][11]. Diberikan data berpasangan $\left(x_{1 i}, x_{2 i}, \ldots, x_{p i}, y_{i}\right), i=$ $1,2, \ldots, n$ dan hubungan kedua data tersebut diasumsikan mengikuti model regresi nonparametrik dengan persamgan sebagai berikut [12].

$$
y_{i}=f\left(x_{1 i}, x_{2 i}, \ldots, x_{p i}\right)+\varepsilon_{i}, i=1,2, \ldots, n
$$

dimana error random $\varepsilon_{i}$ diasumsikan identik, independen, dan berdistribusi normal dengan $E\left(\varepsilon_{i}\right)=0$ dan $\operatorname{var}\left(\varepsilon_{i}\right)=\sigma^{2}$. Apabila kurva regresi $f$ merupakan model aditif, maka dapat dijabarkan menjadi [13]:

$$
\begin{aligned}
f\left(x_{1 i}, x_{2 i}, \ldots, x_{p i}\right) & =f_{1}\left(x_{1 i}\right)+f_{2}\left(x_{2 i}\right)+\ldots+f_{p}\left(x_{p i}\right) \\
& =\sum_{j=1}^{p} f_{j}\left(x_{j i}\right), i=1,2, \ldots, n
\end{aligned}
$$

Fungsi spline truncated diperoleh berdasarkan penjumlahan antara fungsi polinomial dengan fungsi truncated. Kurva regresi $f_{j}\left(x_{j i}\right)$ diasumsikan termuat pada ruang spline berorde $m$ dengan titik-titik knot $K_{1 j}, K_{2 j}, \ldots, K_{r j}$ $; j=1,2, \ldots, p$ diberikan oleh persamaan berikut [12].

$$
f_{j}\left(x_{j i}\right)=\sum_{u=0}^{m} \beta_{j u} x_{j i}{ }^{u}+\sum_{k=1}^{r} \beta_{j(m+k)}\left(x_{j i}-K_{j k}\right)_{+}^{m}
$$

Sehingga diperoleh persamaan model regresi nonparametrik spline truncated multivariabel sebagai berikut [12].

$$
y_{i}=\beta_{0}^{*}+\sum_{j=1}^{p} \sum_{u=1}^{m} \beta_{j u} x_{j i}{ }^{u}+\sum_{j=1}^{p} \sum_{k=1}^{r} \beta_{j(m+k)}\left(x_{j i}-K_{j k}\right)_{+}^{m}+\varepsilon_{i}
$$

Fungsi $\left(x_{j i}-K_{j k}\right)_{+}^{m}$ merupakan fungsi truncated yang diberikan oleh [12]:

$$
\left(x_{j i}-K_{j k}\right)_{+}^{m}= \begin{cases}\left(x_{j i}-K_{j k}\right)^{m}, & x_{j i} \geq K_{j k} \\ 0 & , x_{j i}<K_{j k}\end{cases}
$$

dengan

$\beta_{j u}:$ parameter model polinomial, $j=1,2, \ldots, p ;$

$$
u=0,1, \ldots, m
$$

$x_{j i} \quad$ : variabel prediktor $j \mathrm{ke}-i, i=1,2, \ldots, n$

$\beta_{j(m+k)}$ : parameter komponen truncated, $k=1,2, \ldots, r$

$r \quad$ : banyak knot

$K_{j k} \quad:$ titik-titik knot

\section{Estimasi Parameter}

Estimasi parameter model regresi nonparametrik spline truncated menggunakan metode OLS (Ordinary Least Square) sebagai berikut.

$$
Q(\underset{\sim}{\boldsymbol{\beta}})=\sum_{i=1}^{n} \varepsilon_{i}^{2}
$$

Dapat ditulis dalam bentuk matriks pada persamaan berikut [14].

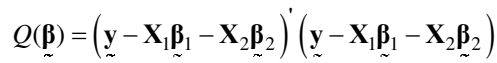

$$
\begin{aligned}
& =(\underset{\sim}{\mathbf{y}}-\mathbf{X} \underset{\sim}{\boldsymbol{\beta}})^{\prime}(\underset{\sim}{\mathbf{y}}-\mathbf{X} \boldsymbol{\beta}) \\
& =\left(\underset{\sim}{\mathbf{y}}-\mathbf{X}^{\prime} \boldsymbol{\beta}^{\prime}\right)(\underset{\sim}{\mathbf{y}}-\mathbf{X} \boldsymbol{\beta}) \\
& =\underset{\sim}{\mathbf{y}} \underbrace{\mathbf{y}}_{\sim}-\boldsymbol{\beta}^{\prime} \mathbf{X}^{\prime} \underset{\sim}{\mathbf{y}}-\underset{\sim}{\mathbf{y}} \mathbf{X} \boldsymbol{\mathbf { \beta }}+\boldsymbol{\beta}_{\sim}^{\prime} \mathbf{X}^{\prime} \mathbf{X} \boldsymbol{\sim}
\end{aligned}
$$

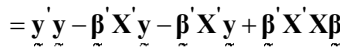

$$
\begin{aligned}
& =\underbrace{\mathbf{y}}_{\sim} \mathbf{\sim}-2 \boldsymbol{\beta}^{\prime} \mathbf{X}^{\prime} \mathbf{\sim}+\boldsymbol{\beta}^{\prime} \mathbf{X}^{\prime} \mathbf{X} \boldsymbol{\beta}
\end{aligned}
$$

Selanjutnya diselesaikan dengan metode derivatif parsial hingga diperoleh persamaan sebagai berikut.

$$
\begin{aligned}
& \frac{\partial Q(\underset{\sim}{\boldsymbol{\beta}})}{\partial \underset{\sim}{\boldsymbol{\beta}}}=0 \\
& -2 \mathbf{X}^{\prime} \underset{\sim}{\mathbf{y}}+2\left(\mathbf{X}^{\prime} \mathbf{X}\right) \underset{\sim}{\hat{\boldsymbol{\beta}}}=0 \\
& \left(X^{\prime} \mathbf{X}\right) \hat{\boldsymbol{\beta}}=\mathbf{X}^{\prime} \mathbf{y} \\
& \left(\mathbf{X}^{\prime} \mathbf{X}\right)^{-1}\left(\mathbf{X}^{\prime} \mathbf{X}\right) \underset{\sim}{\hat{\boldsymbol{\beta}}}=\left(\mathbf{X}^{\prime} \mathbf{X}\right)^{-1} \mathbf{X}^{\prime} \underbrace{\mathbf{y}}_{\sim} \\
& \hat{\boldsymbol{\beta}}=\left(\mathbf{X}^{\prime} \mathbf{X}\right)^{-1} \mathbf{X}^{\prime} \mathbf{y}
\end{aligned}
$$

\section{Pemilihan Titik Knot Optimal}

Model regresi nonparametrik spline truncated dikatakan baik apabila memiliki titik knot optimum. Knot merupakan titik dari sebuah garis regresi untuk membentuk region dari suatu fungsi regresi [15]. Salah satu metode yang sering digunakan untuk menentukan titik knot optimum adalah Generalized Cross Validation (GCV). Titik knot optimum diperoleh berdasarkan nilai GCV yang minimum. Metode GCV dituliskan pada persamaan berikut [16]. 


$$
\operatorname{GCV}\left(K_{1}, K_{2}, \ldots, K_{r}\right)=\frac{\operatorname{MSE}\left(K_{1}, K_{2}, \ldots, K_{r}\right)}{\left[n^{-1} \operatorname{trace}\left(\mathbf{I}-\mathbf{A}\left(K_{1}, K_{2}, \ldots, K_{r}\right)\right)\right]^{2}}
$$

dengan

$$
\operatorname{MSE}\left(K_{1}, K_{2}, \ldots, K_{r}\right)=n^{-1} \sum_{i=1}^{n}\left(y_{i}-\hat{f}\left(x_{i}\right)\right)^{2}
$$

dimana I merupakan matriks identitas, $n$ adalah jumlah pengamatan, dan $K_{1}, K_{2}, \ldots, K_{r}$ merupakan titik-titik knot serta $\mathbf{A}=\mathbf{X}\left(\mathbf{X}^{\mathbf{T}} \mathbf{X}\right)^{-1} \mathbf{X}^{\mathbf{T}}$

\section{E. Koefisien Determinasi $\left(R^{2}\right)$}

Semakin tinggi nilai $\mathrm{R}^{2}$ yang dihasilkan suatu model, maka semakin baik pula variabel-variabel prediktor dalam model tersebut dalam menjelaskan variabilitas variabel respon [7]. Berikut ini adalah rumus untuk menghitung nilai $\mathrm{R}^{2}$.

$$
\mathrm{R}^{2}=1-\frac{S S E}{S S T}
$$

\section{F. Pengujian Parameter Model}

\section{Uji Serentak}

Uji serentak dilakukan untuk mengetahui apakah variabel prediktor dalam model memberikan pengaruh secara keseluruhan. Berikut merupakan tabel ANOVA pada pengujian parameter secara serentak untuk model regresi nonparametrik spline truncated.

Tabel 1.

Tabel ANOVA Model Regresi

\begin{tabular}{ccccc}
\hline $\begin{array}{c}\text { Sumber } \\
\text { variasi }\end{array}$ & df & $\begin{array}{c}\text { Sum of Square } \\
(\mathrm{SS})\end{array}$ & $\begin{array}{c}\text { Mean Square } \\
(\mathrm{MS})\end{array}$ & $F_{\text {hitung }}$ \\
\hline Regresi & $m+r$ & $\sum_{i=1}^{n}\left(\hat{y}_{i}-\bar{y}\right)^{2}$ & $\frac{S S_{\text {regresi }}}{d f_{\text {regresi }}}$ & \\
Error & $n-(m+r)-1$ & $\sum_{i=1}^{n}\left(y_{i}-\hat{y}_{i}\right)^{2}$ & $\frac{S S_{\text {error }}}{d f_{\text {error }}}$ & $\frac{M S_{\text {regresi }}}{M S_{\text {error }}}$ \\
Total & $n-1$ & $\sum_{i=1}^{n}\left(y_{i}-\bar{y}\right)^{2}$ & - & \\
\hline \hline
\end{tabular}

Perumusan hipotesis pada uji serentak adalah sebagai berikut.

$\mathrm{H}_{0}: \beta_{1}=\beta_{2}=\ldots=\beta_{m+r}=0$

$\mathrm{H}_{1}$ : minimal ada satu $\beta_{j} \neq 0 ; \mathrm{j}=1,2, \ldots, m+r$

Statistik uji :

$$
F_{\text {hitung }}=\frac{M S R}{M S E}
$$

Daerah penolakan $\mathrm{H}_{0}$ adalah $F_{\text {hitung }}>F_{(m+r, n-(m+r)-1 ; \alpha)}$ atau $P$ value $<\alpha$.

\section{Uji Parsial}

Uji parsial digunakan untuk mendeteksi apakah parameter secara individual mempunyai pengaruh yang signifikan terhadap variabel respon.

Hipotesis :

$$
\begin{aligned}
& \mathrm{H}_{0}: \beta_{j}=0 \\
& \mathrm{H}_{1}: \beta_{j} \neq 0, j=1,2, \ldots, m+r
\end{aligned}
$$

Statistik uji:

$$
t_{\text {hitung }}=\frac{\hat{\beta}_{j}}{\hat{\operatorname{SE}}\left(\hat{\beta}_{j}\right)}
$$

dengan $\hat{S E}\left(\hat{\beta}_{j}\right)$ adalah standart error $\hat{\beta}_{j}$ yang diperoleh dari akar elemen diagonal ke-j, $j=1,2, \ldots, m+r$ dari matriks variance-covariance $\hat{\operatorname{Var}}(\hat{\beta})$ sebagai berikut.

$$
\begin{aligned}
\hat{\operatorname{Var}}(\hat{\boldsymbol{\beta}}) & =\hat{\operatorname{var}}\left[\left(\mathbf{X}^{\prime} \mathbf{X}\right)^{-1} \mathbf{X}_{\%}^{\prime} \mathbf{y}\right] \\
& =\left(\mathbf{X}^{\prime} \mathbf{X}\right)^{-1} \mathbf{X}^{\prime} \hat{\operatorname{var}(\mathbf{y})}\left[\left(\mathbf{X}^{\prime} \mathbf{X}\right)^{-1} \mathbf{X}^{\prime} \mathbf{X}\right] \\
& =\left(\mathbf{X}^{\prime} \mathbf{X}\right)^{-1} \mathbf{X}^{\prime}\left(\sigma^{2} \mathbf{I}\right) \mathbf{X}\left(\mathbf{X}^{\prime} \mathbf{X}\right)^{-1} \\
& =\sigma^{2}\left(\mathbf{X}^{\prime} \mathbf{X}\right)^{-1} \mathbf{X}^{\prime} \mathbf{X}\left(\mathbf{X}^{\prime} \mathbf{X}\right)^{-1} \\
& =\sigma^{2}\left(\mathbf{X}^{\prime} \mathbf{X}\right)^{-1}
\end{aligned}
$$

Pada umumnya variansi populasi $\sigma^{2}$ tidak diketahui. Oleh karena itu, $\sigma^{2}$ diestimasi dengan menggunakan MSE [12]. Keputusan $\mathrm{H}_{0}$ ditolak apabila $\left|t_{\text {hitung }}\right|>t_{(n-(m+r)-1 ; \alpha / 2)}$ atau $P$-value $<\alpha$.

\section{G. Pengujian Asumsi Residual}

1. Uji Asumsi Identik

Asumsi identik terpenuhi apabila varians antar residual homogen dan tidak terjadi heteroskedastisitas [17]. Pengujian dilakukan menggunakan uji Glejser dengan hipotesis sebagai berikut.

$\mathrm{H}_{0}: \beta_{1}=\beta_{2}=\ldots=\beta_{p}=0$

$\mathrm{H}_{1}$ : minimal ada satu $\beta_{j} \neq 0 ; i=1,2, \ldots, p$

Statistik uji:

$$
F_{\text {hitung }}=\frac{\sum_{i=1}^{n}\left(\left(\left|\hat{e}_{i}\right|-|\bar{e}|\right)^{2}\right) /(p)}{\sum_{i=1}^{n}\left(\left(\left|e_{i}\right|-\left|\hat{e}_{i}\right|\right)^{2}\right) /(n-p-1)}
$$

Tolak $\mathrm{H}_{0}$ apabila $F_{\text {hitung }}>F_{(p,(n-p-1) ; \alpha)}$ atau $P$-value $<\alpha$.

2. Uji Asumsi Independen

Asumsi kedua yaitu ssumsi independen yang berarti tidak terdapat autokorelasi atau korelasi antar residual. Uji yang digunakan untuk mendeteksi kasus autokorelasi adalah uji Durbin-Watson yang hanya autokorelasi pada lag pertama dengan hipotesis sebagai berikut [7].

$\mathrm{H}_{0}: \rho_{1}=0$ (tidak terjadi autokorelasi)

$\mathrm{H}_{1}: \rho_{1} \neq 0$ (terjadi autokorelasi)

Statistik Uji :

$$
d=\frac{\sum_{i=2}^{n}\left(e_{i}-e_{i-1}\right)^{2}}{\sum_{i=1}^{n} e_{i}^{2}}
$$

Daerah keputusan terbagi menjadi beberapa bagian yaitu:

a. Jika $d<d_{L}$ atau $(4-d)<d_{L}$, maka tolak $\mathrm{H}_{0}$.

b. Jika $d>d_{\mathrm{U}}$ atau $(4-d)>d_{\mathrm{U}}$, maka gagal tolak $\mathrm{H}_{0}$.

c. Jika $d_{L} \leq d \leq d_{\mathrm{U}}$ atau $d_{L} \leq(4-d) \leq d_{\mathrm{U}}$, maka tidak ada keputusan.

3. Uji Asumsi Distribusi Normal

Pengujian asumsi distribusi normal dapat menggunakan uji Kolmogorov Smirnov [18]. Hipotesis yang digunakan adalah sebagai berikut.

$\mathrm{H}_{0}: F_{n}(\varepsilon)=F_{0}(\varepsilon) \quad$ (residual mengikuti distribusi normal)

$\mathrm{H}_{1}: F_{n}(\varepsilon) \neq F_{0}(\varepsilon) \quad$ (residual tidak mengikuti distribusi

Statistik uji : normal)

$$
D=\operatorname{Sup}_{\varepsilon}\left|F_{n}(\varepsilon)-F_{0}(\varepsilon)\right|
$$


Daerah penolakan adalah $|D|>q_{(1-\alpha)}$ pada tabel Kolmogorov Smirnov atau $P$-value $<\alpha$.

\section{H. Metode Kontrasepsi Jangka Panjang}

MKJP adalah alat/cara kontrasepsi yang dapat dipakai dalam jangka waktu lama, lebih dari dua tahun, efektif dan efisien untuk tujuan pemakaian menjarangkan kelahiran lebih dari tiga tahun atau mengakhiri kehamilan pada pasangan yang sudah tidak ingin menambah anak lagi [3]. Jenis metode yang termasuk dalam kelompok MKJP antara lain [19]:

1. IUD (Intra Uterine Device) atau alat kontrasepsi dalam rahim merupakan kontrasepsi non hormonal yang dipasang di dalam rahim, contohnya spiral.

2. MOW (Metode Operasional Wanita) atau tubektomi merupakan tindakan pengikatan atau pemotongan kedua saluran telur (Tuba Fallopi) yang menyebabkan sel telur (ovum) dari indung telur (ovarium) tidak akan mencapai uterus dan tidak bertemu dengan sperma, sehingga tidak terjadi kehamilan.

3. MOP (Metode Operasional Pria) atau vasektomi dilakukan dengan cara memotong vas deferens sehingga alur transportasi sperma terhambat dan fertilisasi tidak terjadi.

4. Implant atau Susuk merupakan alat kontrasepsi yang disisipkan atau dipasang di bawah kulit.

\section{METODOLOGI PENELITIAN}

\section{A. Sumber Data}

Sumber data yang digunakan adalah data sekunder dengan unit pengamatan 38 kabupaten/kota di Provinsi Jawa Timur. Data diperoleh dari Publikasi Badan Pusat Statistik (BPS) antara lain Statistik Kesejahteraan Rakyat Provinsi Jawa Timur Tahun 2016, Provinsi Jawa Timur Dalam Angka Tahun 2017, dan data mikro Survei Sosial Ekonomi Nasional (SUSENAS) Tahun 2016.

\section{B. Variabel Penelitian}

Berikut merupakan variabel-variabel yang digunakan pada penelitian ini.

Tabel 2.

Variabel Penelitian

\begin{tabular}{|c|c|c|}
\hline Variabel & Keterangan & Skala \\
\hline$y$ & Persentase Peserta KB Aktif MKJP & Rasio \\
\hline$x_{1}$ & $\begin{array}{l}\text { Persentase Perempuan Usia 15-49 Tahun } \\
\text { Berstatus Kawin Memiliki Anak Masih Hidup } \\
\text { Lebih Dari Dua }\end{array}$ & Rasio \\
\hline$x_{2}$ & $\begin{array}{l}\text { Persentase Perempuan Usia 15-49 Tahun } \\
\text { Berstatus Kawin dengan Pendidikan Tertinggi } \\
\text { yang Ditamatkan Minimal SMP sederajat }\end{array}$ & Rasio \\
\hline$x_{3}$ & $\begin{array}{l}\text { Persentase Perempuan Usia } 35 \text { Tahun Keatas } \\
\text { Berstatus Kawin }\end{array}$ & Rasio \\
\hline$x_{4}$ & $\begin{array}{llll}\text { Persentase Perempuan Usia } & 15-49 \text { Tahun } \\
\text { Berstatus Kawin Pernah } & \text { Menggunakan } \\
\text { Alat/Cara KB } & & \end{array}$ & Rasio \\
\hline$x_{5}$ & $\begin{array}{l}\text { Persentase Perempuan Usia } 15-49 \text { Tahun } \\
\text { Berstatus Kawin yang Bekerja }\end{array}$ & Rasio \\
\hline$x_{6}$ & $\begin{array}{l}\text { Persentase Perempuan Usia } 15 \text { Tahun Keatas } \\
\text { Berstatus Kawin dengan Usia Kawin Pertama } \\
\text { Kurang Dari } 19 \text { Tahun }\end{array}$ & Rasio \\
\hline
\end{tabular}

\section{Langkah-Langkah Penelitian}

Langkah-langkah dalam penelitian ini adalah sebagai berikut.
1. Menganalisis karakteristik persentase peserta $\mathrm{KB}$ aktif MKJP berdasarkan faktor-faktor yang diduga berpengaruh di Provinsi Jawa Timur tahun 2016.

2. Pemodelan persentase peserta KB aktif MKJP setiap kabupaten/kota di Provinsi Jawa Timur berdasarkan faktor-faktor yang diduga berpengaruh menggunakan model regresi nonparametrik spline truncated. Langkahlangkah yang dilakukan adalah sebagai berikut.

a. Membuat scatter plot antara variabel respon dengan masing-masing variabel prediktor untuk identifikasi pola data yang terbentuk.

b. Melakukan analisis menggunakan regresi linier berganda untuk mengetahui hubungan antara faktorfaktor yang diduga berpengaruh di kabupaten/kota Provinsi Jawa Timur dengan persentase peserta KB aktif MKJP.

c. Memodelkan data menggunakan pendekatan spline dengan satu, dua, tiga, serta kombinasi titik knot.

d. Memilih titik knot optimum berdasarkan nilai GCV yang paling minimum.

e. Membuat model regresi nonparametrik spline truncated dengan titik knot optimum.

f. Melakukan pengujian signifikansi parameter secara serentak dan pengujian secara parsial.

g. Melakukan pengujian asumsi residual identik, independen, dan distribusi normal (IIDN) dari model regresi nonparametrik spline truncated.

h. Mengintepretasikan model dan menarik kesimpulan.

\section{ANALISIS DAN PEMBAHASAN}

A. Karakteristik Persentase Peserta KB Aktif MKJP di Provinsi Jawa Timur

Karakteristik persentase peserta KB aktif MKJP setiap kabupaten/kota di Provinsi Jawa Timur beserta faktor-faktor yang diduga berpengaruh disajikan pada Tabel 3 .

Tabel 3.

Statistika Deskriptif Variabel Penelitian

\begin{tabular}{crrrr}
\hline \hline Variabel & Rata-rata & Varians & Minimum & Maksimum \\
\hline$y$ & 30,43 & 78,95 & 12,66 & 53,01 \\
$x_{1}$ & 17,922 & 31,751 & 10,410 & 35,950 \\
$x_{2}$ & 52,22 & 188,03 & 25,47 & 81,64 \\
$x_{3}$ & 71,891 & 13,128 & 64,870 & 80,820 \\
$x_{4}$ & 10,217 & 14,692 & 4,260 & 21,150 \\
$x_{5}$ & 55,31 & 65,20 & 38,24 & 75,05 \\
$x_{6}$ & 38,37 & 208,91 & 14,60 & 70,76 \\
\hline \hline
\end{tabular}

Tabel 3 menunjukkan karakteristik dari variabel respon (y) yaitu persentase peserta KB aktif MKJP setiap kabupaten/ kota di Provinsi Jawa Timur pada tahun 2016 memiliki rata-rata sebesar $30,43 \%$. Persentase peserta KB aktif MKJP terendah sebesar $12,66 \%$ berada di Kab. Sumenep, sedangkan tertinggi sebesar $53,01 \%$ berada di Kab. Ponorogo. Kab. Sumenep dengan persentase peserta KB aktif MKJP terendah perlu meningkatan kembali program KB terutama KB dengan menggunakan MKJP.

Variabel $x_{1}$ merupakan persentase perempuan usia 15-49 tahun berstatus kawin memiliki anak masih hidup lebih dari dua. Nilai rata-rata sebesar $17,922 \%$. Persentase tertinggi terdapat di Kab. Bangkalan sebesar 35,950\%. Persentase terendah berada di Kab. Pacitan dengan nilai sebesar $10,410 \%$. Variabel $x_{2}$ merupakan persentase perempuan usia 15-49 tahun berstatus kawin dengan pendidikan tertinggi yang ditamatkan minimal SMP sederajat memiliki nilai ratarata sebesar 52,22\%. Nilai tertinggi terdapat di Kota Madiun 
sebesar $81,64 \%$. Nilai terendah terdapat di Kab. Sampang sebesar 25,47\%. Variabel $x_{3}$ merupakan persentase perempuan usia 35 tahun keatas berstatus kawin memiliki rata-rata sebesar $71,891 \%$. Persentase tertinggi berada di Kab. Magetan sebesar 80,82\%. Persentase terendah terdapat di Kab. Sampang sebesar 64,870. Variabel $x_{4}$ merupakan persentase perempuan usia 15-49 tahun berstatus kawin pernah menggunakan alat/cara KB memiliki nilai rata-rata sebesar 10,217\%. Nilai tertinggi terdapat di Kab. Pamekasan yakni $21,150 \%$. Nilai terendah terdapat di Kab. Pasuruan yakni $4,260 \%$. Variabel $x_{5}$ merupakan persentase perempuan usia 15-49 tahun berstatus kawin yang bekerja memiliki rata-rata sebesar $55,31 \%$. Persentase tertinggi terdapat di Kab. Pacitan sebesar 75,05\%. Persentase terendah terdapat di Kab. Jember sebesar 38,24\%. Variabel $x_{6}$ merupakan persentase perempuan usia 15 tahun keatas berstatus kawin dengan usia kawin pertama kurang dari 19 tahun memiliki nilai rata-rata sebesar $38,37 \%$. Kab. Bondowoso memiliki persentase tertinggi yaitu sebesar 70,76\%. Sedangkan persentase terendah berada di Kab. Sidoarjo sebesar $14,60 \%$.

Terdapat 15 kabupaten/kota di Provinsi Jawa Timur yang masih berada di bawah persentase peserta $\mathrm{KB}$ aktif MKJP Provinsi Jawa Timur keseluruhan, yaitu 28,72\%. Meskipun sebagian besar kabupaten/kota memiliki nilai lebih besar dari persentase peserta KB aktif MKJP Provinsi Jawa Timur keseluruhan, namun pemakaian MKJP di Jawa Timur masih rendah dibandingkan pemakaian non-MKJP. Sehingga perlu ditingkatkan karena MKJP lebih efektif dan efisien dalam menurunkan fertilitas.

\section{B. Pemodelan Menggunakan Regresi Linier Berganda}

Penelitian ini ingin menganalisis pemodelan persentase peserta KB aktif MKJP menggunakan regresi linier berganda terlebih dahulu sebelum pemodelan dengan regresi nonparametrik spline truncated. Pada analisis diperoleh model regresi seperti persamaan berikut.

$\hat{y}=25,9-0,633 x_{1}-0,130 x_{2}+0,516 x_{3}+0,160 x_{4}-0,067 x_{5}-0,322 x_{6}$ Hasil pengujian parsial model regresi linier berganda ditunjukkan pada Tabel 4.

Tabel 4.

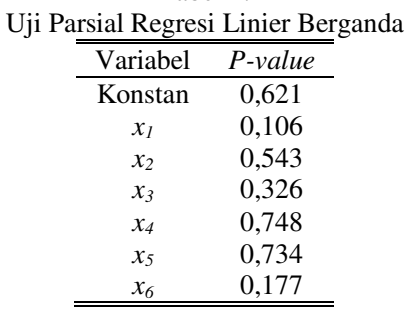

Berdasarkan analisis pemodelan menggunakan regresi linier berganda tersebut, diperoleh nilai $R^{2}$ yang kecil yakni sebesar $33,99 \%$ dan semua variabel prediktor tidak berpengaruh signifikan terhadap persentase peserta KB aktif MKJP dilihat pada Tabel 4 semua variabel prediktor memiliki $P$-value $>\alpha=0,05$. Oleh karena itu, penelitian ini dilakukan pemodelan menggunakan regresi nonparametrik spline truncated dengan kemungkinan hasil yang lebih baik.

\section{Pola Hubungan Persentase Peserta KB Aktif MKJP dengan Faktor-Faktor yang Diduga Berpengaruh}

Pola hubungan antara variabel respon dan variabel prediktor dapat diidentifikasi menggunakan scatterplot untuk mengetahui apakah terdapat pola hubungan tertentu atau tidak. Berikut merupakan scatterplot yang mendeteksi bentuk pola hubungan antara persentase peserta $\mathrm{KB}$ aktif MKJP dan faktor-faktor yang diduga mempengaruhinya.

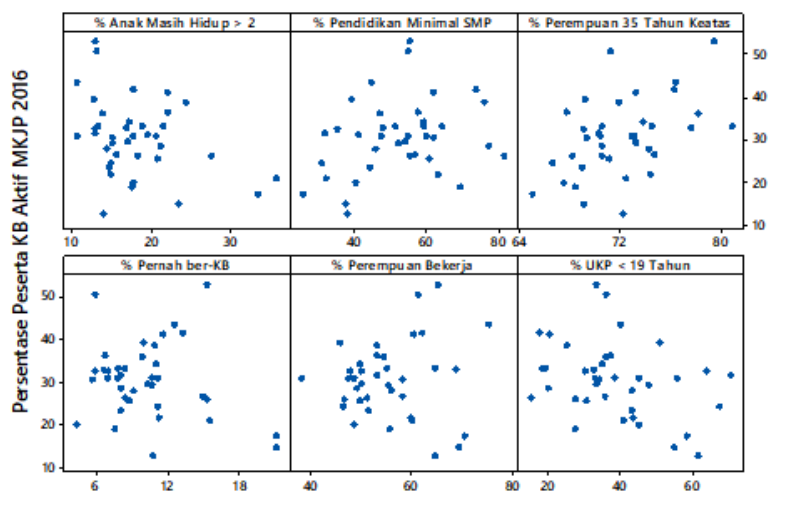

Gambar 1. Pola Hubungan Persentase Peserta KB Aktif MKJP dengan Variabel Prediktor.

Berdasarkan Gambar 1. diketahui bahwa seluruh variabel prediktor tidak membentuk pola tertentu atau sebaran data acak. Sehingga metode yang digunakan adalah regresi nonparametrik spline truncated.

\section{Pemilihan Titik Knot Optimum}

Nilai GCV minimum pada pemilihan titik knot optimum dengan satu titik knot, dua titik knot, tiga titik knot, dan kombinasi titik knot disajikan pada Tabel 5.

Tabel 5.

Perbandingan Nilai GCV Minimum Keenam Variabel

\begin{tabular}{cc}
\hline \hline Jumlah Titik Knot & GCV Minimum \\
\hline Satu Knot & 85,85 \\
Dua Knot & 65,76 \\
Tiga Knot & 36.09 \\
Kombinasi Knot $(2,3,3,3,1,3)$ & 30,48 \\
\hline \hline
\end{tabular}

Berdasarkan Tabel 5 diketahui bahwa nilai GCV paling minimum yaitu sebesar 30,48 terletak pada pemodelan dengan kombinasi titik knot $(2,3,3,3,1,3)$.

\section{E. Pengujian Signifikansi Parameter Model Regresi} Nonparametrik Spline Truncated

1. Pengujian Secara Serentak

Berikut adalah perumusan hipotesis pada uji serentak.

$\mathrm{H}_{0}: \beta_{11}=\beta_{12}=\ldots=\beta_{64}=0$

$\mathrm{H}_{1}$ : minimal ada satu $\beta_{j(m+r)} \neq 0 ; j=1,2, \ldots, 6 ; r=0,1, \ldots, 3$

Hasil pengujian secara serentak disajikan pada Tabel 6.

Tabel 6.

ANOVA Pengujian Serentak

\begin{tabular}{cccccc}
\hline \hline $\begin{array}{c}\text { Sumber } \\
\text { Variasi }\end{array}$ & df & SS & MS & F & P-value \\
\hline Regresi & 21 & 2689,298 & 128,0618 & 8,838495 & 0,00003 \\
Error & 16 & 231,8255 & 14,4891 & & \\
Total & 37 & 2921,123 & & & \\
\hline \hline
\end{tabular}

Berdasarkan Tabel 6 diperoleh keputusan tolak $\mathrm{H}_{0}$ karena nilai $\mathrm{F}>\mathrm{F}_{(0,05 ; 21 ; 16)}=1,98$ dan $P$-value $<\alpha=0,05$ sehingga disimpulkan bahwa minimal terdapat satu parameter model yang signifikan. Nilai $R^{2}$ yang diperoleh adalah $94,09 \%$.

2. Pengujian Secara Parsial

Berikut adalah perumusan hipotesis pada uji parsial.

$$
\begin{aligned}
& \mathrm{H}_{0}: \beta_{j(m+r)}=0 \\
& \mathrm{H}_{1}: \beta_{j(m+r)} \neq 0, j=1,2, \ldots, 6 ; r=0,1, \ldots, 3
\end{aligned}
$$


Hasil pengujian signifikansi parameter model regresi secara parsial disajikan pada Tabel 7.

Tabel 7.

Hasil Pengujian Parameter Secara Parsial

\begin{tabular}{|c|c|c|c|c|}
\hline Variabel & Parameter & $\begin{array}{c}\text { Estimasi } \\
\text { Parameter }\end{array}$ & P-value & Kesimpulan \\
\hline \multirow{3}{*}{$x_{1}$} & $\hat{\beta}_{11}$ & 1,32 & 0,39 & Tidak Signifikan \\
\hline & $\hat{\beta}_{12}$ & $-34,24$ & 0,00 & Signifikan \\
\hline & $\hat{\beta}_{13}$ & 32,57 & 0,00 & Signifikan \\
\hline \multirow{4}{*}{$x_{2}$} & $\hat{\beta}_{21}^{10}$ & $-1,59$ & 0,53 & Tidak signifikan \\
\hline & $\hat{\beta}_{22}$ & $-9,12$ & 0,24 & Tidak signifikan \\
\hline & $\hat{\beta}_{23}$ & 15,73 & 0,12 & Tidak signifikan \\
\hline & $\hat{\beta}_{24}$ & $-5,26$ & 0,16 & Tidak signifikan \\
\hline \multirow{4}{*}{$x_{3}$} & $\hat{\beta}_{31}$ & $-1,22$ & 0,39 & Tidak Signifikan \\
\hline & $\hat{\beta}_{32}$ & 75,81 & 0,00 & Signifikan \\
\hline & $\hat{\beta}_{33}$ & $-130,64$ & 0,00 & Signifikan \\
\hline & $\hat{\beta}_{34}$ & 57,48 & 0,00 & Signifikan \\
\hline \multirow{4}{*}{$x_{4}$} & $\hat{\beta}_{41}$ & 43,67 & 0,00 & Signifikan \\
\hline & $\hat{\beta}_{42}$ & $-69,94$ & 0,00 & Signifikan \\
\hline & $\hat{\beta}_{43}$ & 38,91 & 0,00 & Signifikan \\
\hline & $\hat{\beta}_{44}$ & $-12,37$ & 0,01 & Signifikan \\
\hline \multirow{2}{*}{$x_{5}$} & $\hat{\beta}_{51}$ & $-1,43$ & 0,04 & Signifikan \\
\hline & $\hat{\beta}_{52}$ & 1,09 & 0,13 & Tidak Signifikan \\
\hline \multirow{4}{*}{$x_{6}$} & $\hat{\beta}_{61}$ & 0,27 & 0,82 & Tidak Signifikan \\
\hline & $\hat{\beta}_{62}$ & 7,32 & 0,07 & Tidak Signifikan \\
\hline & $\hat{\beta}_{63}$ & $-17,23$ & 0,01 & Signifikan \\
\hline & $\hat{\beta}_{64}$ & 9,15 & 0,01 & Signifikan \\
\hline
\end{tabular}

Tabel 7 menunjukkan lima variabel yang berpengaruh signifikan yakni persentase perempuan usia 15-49 tahun memiliki anak masih hidup lebih dari dua $\left(x_{1}\right)$, persentase perempuan usia 35 tahun keatas berstatus kawin $\left(x_{3}\right)$, persentase perempuan usia 15-49 tahun berstatus kawin pernah menggunakan alat/cara $\mathrm{KB}\left(x_{4}\right)$, persentase perempuan usia 15-49 tahun berstatus kawin yang bekerja $\left(x_{5}\right)$, dan persentase perempuan usia 15 tahun keatas berstatus kawin dengan usia kawin pertama kurang dari 19 tahun $\left(x_{6}\right)$. Satu variabel yang tidak berpengaruh signifikan yaitu persentase perempuan usia 15-49 tahun berstatus kawin dengan pendidikan terakhir yang ditamatkan minimal SMP sederajat $\left(x_{2}\right)$. Variabel dianggap berpengaruh apabila terdapat minimal satu parameter yang signifikan.

F. Pemilihan Titik Knot Optimum Tanpa Variabel $x_{2}$

Selanjutnya melakukan pemodelan kembali tanpa menyertakan variabel yang tidak signifikan. Berikut nilai GCV minimum pada model tanpa variabel $x_{2}$ ditampilkan pada Tabel 8.

Tabel 8.

Perbandingan Nilai GCV Minimum Tanpa Variabel $x_{2}$

\begin{tabular}{cc}
\hline \hline Jumlah Titik Knot & GCV Minimum \\
\hline Satu Knot & 77,04 \\
Dua Knot & 55,20 \\
Tiga Knot & 31.91 \\
Kombinasi Knot $(3,3,3,3,3)$ & 31,91 \\
\hline \hline
\end{tabular}

Berdasarkan Tabel 8 diketahui bahwa nilai GCV paling minimum sebesar 31,91 terletak pada pemodelan dengan tiga titik knot atau kombinasi titik knot $(3,3,3,3,3)$.

G. Pengujian Signifikansi Parameter Model Regresi Nonparametrik Spline Truncated Tanpa Variabel $x_{2}$

1. Pengujian Secara Serentak

Berikut adalah perumusan hipotesis pada uji serentak.

$\mathrm{H}_{0}: \beta_{11}=\beta_{12}=\ldots=\beta_{64}=0$

$\mathrm{H}_{1}$ : minimal ada satu $\beta_{j(m+r)} \neq 0 ; j=1,2, \ldots, 5 ; r=0,1, \ldots, 3$
Hasil pengujian secara serentak disajikan pada Tabel 9.

Tabel 9.

ANOVA Pengujian Serentak Tanpa Variabel $x_{2}$

\begin{tabular}{cccccc}
\hline \hline $\begin{array}{c}\text { Sumber } \\
\text { Variasi }\end{array}$ & df & SS & MS & F & P-value \\
\hline Regresi & 20 & 2649,068 & 132,4534 & 8,276642 & 0,00003 \\
Error & 17 & 272,0557 & 16,00328 & & \\
Total & 37 & 2921,123 & & & \\
\hline \hline
\end{tabular}

Berdasarkan Tabel 9 diperoleh keputusan tolak $\mathrm{H}_{0}$ karena nilai $\mathrm{F}>\mathrm{F}_{(0,05 ; 20 ; 17)}=2,23$ dan $P$-value $<\alpha=0,05$. Sehingga disimpulkan bahwa minimal terdapat satu parameter model yang signifikan. Nilai $R^{2}$ yang diperoleh adalah $90,69 \%$.

2. Pengujian Secara Parsial

Berikut adalah perumusan hipotesis pada uji parsial.

$$
\begin{aligned}
& \mathrm{H}_{0}: \beta_{j(m+r)}=0 \\
& \mathrm{H}_{1}: \beta_{j(m+r)} \neq 0, j=1,2, \ldots, 5 ; r=0,1, \ldots, 3
\end{aligned}
$$

Hasil pengujian parameter model regresi secara parsial yang disajikan pada Tabel 10.

Tabel 10

Hasil Pengujian Parameter Secara Parsial Tanpa Variabel $x_{2}$

\begin{tabular}{ccccc}
\hline \hline \multirow{2}{*}{ Variabel } & Parameter & $\begin{array}{c}\text { Estimasi } \\
\text { Parameter }\end{array}$ & P-value & Kesimpulan \\
\hline \multirow{4}{*}{$x_{1}$} & $\hat{\beta}_{11}$ & 0,51 & 0,775 & Tidak Signifikan \\
& $\hat{\beta}_{12}$ & $-49,00$ & 0,000 & Signifikan \\
& $\hat{\beta}_{13}$ & 50,63 & 0,000 & Signifikan \\
& $\hat{\beta}_{14}$ & $-2,76$ & 0,003 & Signifikan \\
& $\hat{\beta}_{31}$ & 1,43 & 0,774 & Tidak Signifikan \\
& $\hat{\beta}_{32}$ & $-35,13$ & 0,155 & Tidak Signifikan \\
& $\hat{\beta}_{33}$ & 31,98 & 0,137 & Tidak Signifikan \\
& $\hat{\beta}_{34}$ & 3,59 & 0,014 & Signifikan \\
& $\hat{\beta}_{41}$ & 8,30 & 0,050 & Signifikan \\
& $\hat{\beta}_{42}$ & $-51,49$ & 0,005 & Signifikan \\
& $\hat{\beta}_{43}$ & 46,08 & 0,003 & Signifikan \\
& $\hat{\beta}_{44}$ & $-3,94$ & 0,001 & Signifikan \\
& $\hat{\beta}_{51}$ & $-2,41$ & 0,768 & Tidak Signifikan \\
& $\hat{\beta}_{52}$ & $-4,14$ & 0,931 & Tidak Signifikan \\
& $\hat{\beta}_{53}$ & 8,18 & 0,837 & Tidak Signifikan \\
& $\hat{\beta}_{54}$ & $-2,31$ & 0,003 & Signifikan \\
& $\hat{\beta}_{61}$ & 0,63 & 0,541 & Tidak Signifikan \\
& $\hat{\beta}_{62}$ & $-8,62$ & 0,071 & Tidak Signifikan \\
& $\hat{\beta}_{63}$ & 8,43 & 0,053 & Tidak Signifikan \\
& $\hat{\beta}_{64}$ & $-0,89$ & 0,018 & Signifikan \\
\hline \hline & & & & \\
& & & & \\
& & & &
\end{tabular}

Berdasarkan Tabel 10 diketahui bahwa dengan taraf signifikansi $\alpha$ sebesar 5\%, semua variabel prediktor berpengaruh signifikan terhadap model. Variabel dianggap berpengaruh apabila terdapat minimal satu parameter yang signifikan.

H. Pemodelan Persentase Peserta KB Aktif MKJP di Jawa Timur Menggunakan Titik Knot Optimum Tanpa Variabel $x_{2}$

Estimasi model regresi nonparametrik spline truncated dengan tiga titik knot atau kombinasi titik knot adalah sebagai berikut.

$$
\begin{aligned}
\hat{y}_{i}= & 1,66+0,51 x_{1 i}-49\left(x_{1 i}-13,02\right)_{+}+50,63\left(x_{1 i}-13,54\right)_{+}-2,76\left(x_{1 i}-20,31\right)_{+}+ \\
& 1,43 x_{3 i}-35,13\left(x_{3 i}-66,50\right)_{+}+31,98\left(x_{3 i}-66,82\right)_{+}+3,59\left(x_{3 i}-71,05\right)_{+}+ \\
& 8,30 x_{4 i}-51,49\left(x_{4 i}-5,98\right)_{+}+46,08\left(x_{4 i}-6,33\right)_{+}-3,94\left(x_{4 i}-10,81\right)_{+}- \\
& 2,41 x_{5 i}-4,14\left(x_{5 i}-42\right)_{+}+8,18\left(x_{5 i}-42,75\right)_{+}-2,31\left(x_{5 i}-52,51\right)_{+}+0,63 x_{6 i}- \\
& 8,62\left(x_{6 i}-20,33\right)_{+}+8,43\left(x_{6 i}-21,48\right)_{+}-0,89\left(x_{6 i}-36,38\right)_{+}
\end{aligned}
$$

I. Pengujian Asumsi Residual 
1. Pengujian Asumsi Identik

Pengujian asumsi identik dapat dilakukan menggunakan uji Glejser dengan hipotesis sebagai berikut.

$$
\begin{aligned}
& \mathrm{H}_{0}: \beta_{1}=\beta_{2}=\ldots=\beta_{5}=0 \\
& \mathrm{H}_{1}: \text { minimal ada satu } \beta_{j} \neq 0 ; i=1,2, \ldots, 5
\end{aligned}
$$

Hasil pengujian asumsi identik disajikan pada Tabel 11.

Tabel 11.

Hasil Pengujian Asumsi Identik Residual

\begin{tabular}{cccccc}
\hline \hline Sumber Variasi & df & SS & MS & F & P-value \\
\hline Regresi & 5 & 11,27 & 2,25 & 0,79 & 0,56 \\
Error & 32 & 90,87 & 2,84 & & \\
Total & 37 & 102,14 & & & \\
\hline \hline
\end{tabular}

Tabel 11 diperoleh keputusan gagal tolak $\mathrm{H}_{0}$ karena nilai $\mathrm{F}<\mathrm{F}_{(0,05 ; 5 ; 32)}=2,51$ dan $P$-value $>\alpha=0,05$ sehingga dapat disimpulkan bahwa varians antar residual homogen dan tidak terjadi heteroskedastisitas.

2. Pengujian Asumsi Independen

Pengujian yang digunakan adalah uji Durbin-Watson dengan hipotesis sebagai berikut.

$\mathrm{H}_{0}: \rho_{1}=0$ (tidak terjadi autokorelasi)
$\mathrm{H}_{1}: \rho_{1} \neq 0$ (terjadi autokorelasi)

Berikut adalah hasil pengujian asumsi independen.

Tabel 12.

Hasil Pengujian Asumsi Independen Residual

\begin{tabular}{ccccc}
\hline \hline $\mathrm{d}$ & $\mathrm{T}$ (observasi) & $\mathrm{K}$ (variabel) & $\mathrm{d}_{\mathrm{L}}$ & $\mathrm{d}_{\mathrm{U}}$ \\
\hline 1,894 & 38 & 6 & 1,204 & 1,792 \\
\hline \hline
\end{tabular}

Tabel 12 diperoleh keputusan gagal tolak $\mathrm{H}_{0}$ karena $\mathrm{d}>$ $\mathrm{d}_{\mathrm{U}}$ atau (4-d) $>\mathrm{d}_{\mathrm{U}}$, maka dapat disimpulkan bahwa asumsi independen terpenuhi atau tidak terdapat autokorelasi.

3. Pengujian Asumsi Distribusi Normal

Pengujian dapat menggunakan uji Kolmogorov-Smirnov dengan hipotesis sebagai berikut.

$\mathrm{H}_{0}: F_{n}(\varepsilon)=F_{0}(\varepsilon) \quad$ (residual berdistribusi normal)

$\mathrm{H}_{1}: F_{n}(\varepsilon) \neq F_{0}(\varepsilon) \quad$ (residual tidak berdistribusi normal)

Hasil pengujian ditunjukkan pada Gambar 2.

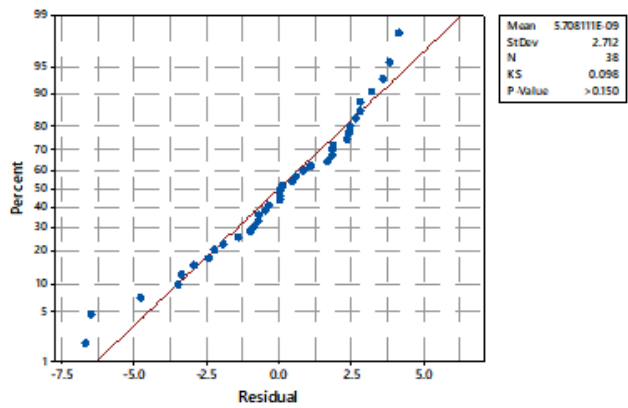

Gambar 2. Plot distribusi normal residual.

Gambar 2 menunjukkan nilai Kolmogorov-Smirnov sebesar 0,098 lebih kecil dibandingkan $q_{(1-\alpha)}$ pada taraf signifikansi $\alpha=0,05$ yaitu 0,215 dan $P$-value sebesar $>0,150$, maka gagal tolak $\mathrm{H}_{0}$. Hal ini menunjukkan bahwa residual telah memenuhi asumsi distribusi normal.

\section{J. Perbandingan Hasil Pemodelan}

Perbandingan pemodelan menggunakan regresi linier berganda dan regresi nonparametrik spline truncated terlihat pada hasil koefisien determinasi sebagai berikut.

Tabel 13.

Perbandingan Hasil Pemodelan

Pemodelan $R^{2}$

\begin{tabular}{cc}
\hline \hline Regresi Linier Berganda & $33,99 \%$ \\
\hline $\begin{array}{c}\text { Regresi Nonparametrik Spline } \\
\text { Truncated }\end{array}$ & $90,69 \%$ \\
\hline \hline
\end{tabular}

Tabel 13 menunjukkan hasil $R^{2}$ pemodelan regresi linier berganda hanya sebesar 33,99\% lebih rendah dibandingkan pemodelan pada regresi nonparametrik spline truncated yang mencapai 90,69\%. Selain itu, pengujian parsial regresi linier berganda pada Tabel 4 semua variabel prediktor tidak berpengaruh signifikan yang terlihat pada $P$-value lebih besar dari $\alpha=0,05$. Sedangkan pengujian parsial regresi nonparametrik spline truncated pada Tabel 10 kelima variabel prediktor berpengaruh signifikan. Oleh karena itu, pada penelitian ini menggunakan pemodelan dengan regresi nonparametrik spline truncated karena memiliki hasil lebih baik.

\section{K. Perbandingan Pemetaan Persentase Peserta KB Aktif MKJP di Provinsi Jawa Timur}

Hasil perbandingan data asli persentase peserta KB aktif MKJP dengan data nilai dugaan dari model terbaik yang diperoleh menggunakan regresi nonparametrik spline truncated dapat dilihat berdasarkan peta sebagai berikut.
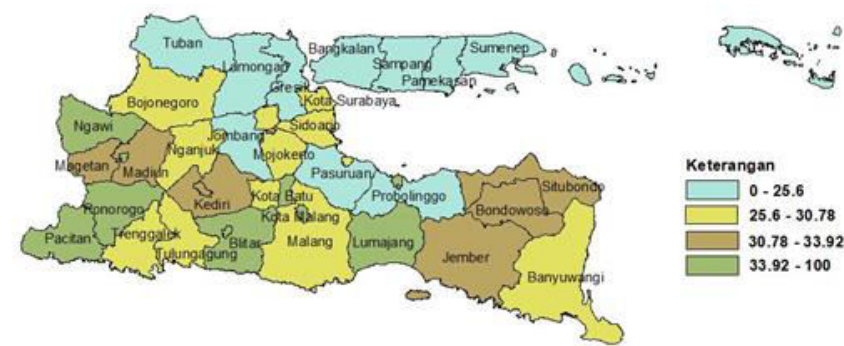

Gambar 3. Peta Persentase Peserta KB Aktif MKJP di Provinsi Jawa Timur.

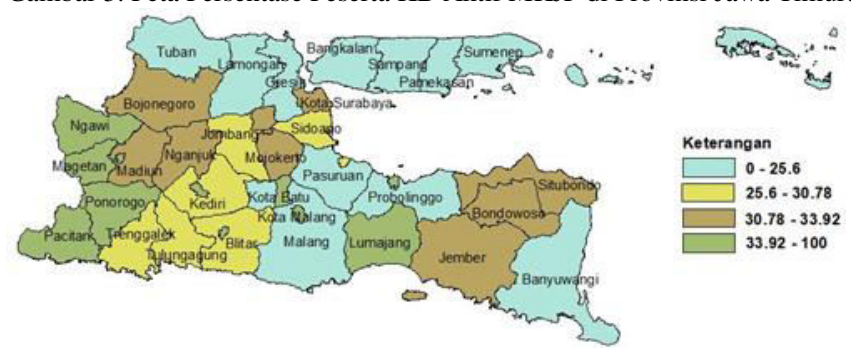

Gambar 4. Peta Nilai Dugaan Persentase Peserta KB Aktif MKJP di Provinsi Jawa Timur.

Klasifikasi daerah berdasarkan persentase peserta KB aktif MKJP diperoleh dari nilai kuartil data asli dimana dapat dibedakan menjadi 4 yaitu kategori rendah $(<25.6 \%)$, kategori sedang $(25.6-$ $29.78 \%$ ), kategori tinggi (30.78-32.92\%), dan kategori sangat tinggi ( $\geq 33.92 \%$ ). Gambar 3 merupakan peta pada data persentase peserta KB aktif MKJP di Provinsi Jawa Timur (y), sedangkan Gambar 4 merupakan peta pada nilai dugaan model terbaik yang diperoleh dengan regresi nonparametrik spline truncated $(\hat{y})$. Berdasarkan kedua gambar tersebut dari 38 kabupaten/kota di Provinsi Jawa Timur terdapat 11 kabupaten/kota yang mengalami perubahan klasifikasi yaitu Kab.Jombang, Kota Surabaya, Kab.Banyuwangi, Kab.Nganjuk, Kab.Mojokerto, Kab.Bojonegoro, Kab.Malang, Kab.Kediri, Kab.Magetan, Kota Kediri, dan Kab.Blitar. Sedangkan kabupaten/kota sisanya tidak mengalami perubahan klasifikasi.

Kab.Jombang yang semula kategori rendah atau terdapat $25,48 \%$ peserta KB aktif MKJP, setelah dilakukan pemodelan terdapat 26,06\% peserta KB aktif MKJP (kategori sedang). Kota Surabaya juga mengalami perubahan yang semula $28,54 \%$ atau kategori sedang, menjadi 32,62\% (kategori tinggi) setelah dilakukan pemodelan. Kab.Banyuwangi yang semula termasuk kategori sedang yakni $29,12 \%$, setelah pemodelan terdapat $23,80 \%$ (kategori rendah). Selain itu, Kab.Nganjuk semula terdapat 29,45\% atau termasuk kategori sedang menjadi $31,28 \%$ (kategori tinggi) setelah pemodelan. Kab.Mojokerto mengalami perubahan yang semula kategori sedang yakni $30,48 \%$, setelah pemodelan menjadi 
$32,58 \%$ (kategori tinggi). Kab.Bojonegoro yang semula terdapat $30,78 \%$ atau kategori sedang, menjadi $32,11 \%$ (kategori tinggi). Kab.Malang semula termasuk kategori sedang atau terdapat 30,78\% peserta KB aktif MKJP, mengalami perubahan setelah pemodelan yakni $24,89 \%$ (kategori rendah). Kab.Kediri yang semula terdapat $30,9 \%$ atau temasuk kategori tinggi, menjadi kategori sedang yakni $28,34 \%$ setelah pemodelan. Kab.Magetan semula termasuk kategori tinggi yakni terdapat $33,06 \%$, berubah menjadi kategori sangat tinggi atau terdapat $34,81 \%$ peserta $\mathrm{KB}$ aktif MKJP. Kota Kediri mengalami hal yang serupa yaitu semula terdapat 33,22\% atau kategori tinggi menjadi 35,09\% (kategori sangat tinggi) setelah pemodelan. Kemudian Kab.Blitar yang semula kategori sangat tinggi atau terdapat $34,15 \%$ mengalami perubahan setelah dilakukan pemodelan menjadi $30,11 \%$ (kategori sedang).

\section{KESIMPULAN DAN SARAN}

\section{A. Kesimpulan}

Beberapa kesimpulan yang didapatkan dari hasil analisis adalah sebagai berikut.

1. Persentase peserta KB aktif MKJP setiap kabupaten/kota di Provinsi Jawa Timur tahun 2016 terendah sebesar $12,66 \%$ berada di Kab.Sumenep. Sedangkan persentase terendah di Kab.Ponorogo sebesar 53,01\%. Terdapat 15 kabupaten/kota di Provinsi Jawa Timur yang masih dibawah persentase peserta KB aktif MKJP Provinsi Jawa Timur keseluruhan $(28,72 \%)$.

2. Analisis pemodelan menggunakan regresi linier berganda diperoleh nilai $R^{2}$ sebesar $33,99 \%$ dan semua variabel prediktor tidak berpengaruh signifikan. Oleh karena itu, dilakukan pemodelan dengan regresi nonparametrik spline truncated dengan kemungkinan hasil lebih baik.

3. Lima variabel yang signifikan yaitu persentase perempuan usia 15-49 tahun berstatus kawin memiliki anak masih hidup lebih dari dua, persentase perempuan usia 35 tahun keatas berstatus kawin, persentase perempuan usia 15-49 tahun berstatus kawin pernah menggunakan alat/cara $\mathrm{KB}$, persentase perempuan usia 15-49 tahun berstatus kawin yang bekerja, dan persentase perempuan usia 15 tahun keatas berstatus kawin dengan usia kawin pertama kurang dari 19 tahun. Model regresi nonparametrik spline truncated terbaik yang diperoleh dalam pemodelan yaitu menggunakan tiga titik knot atau kombinasi titik knot $(3,3,3,3,3)$ sebagai berikut.

$$
\begin{aligned}
\hat{y}_{i}= & 1,66+0,51 x_{1 i}-49\left(x_{1 i}-13,02\right)_{+}+50,63\left(x_{1 i}-13,54\right)_{+}-2,76\left(x_{1 i}-20,31\right)_{+}+ \\
& 1,43 x_{3 i}-35,13\left(x_{3 i}-66,50\right)_{+}+31,98\left(x_{3 i}-66,82\right)_{+}+3,59\left(x_{3 i}-71,05\right)_{+}+ \\
& 8,30 x_{4 i}-51,49\left(x_{4 i}-5,98\right)_{+}+46,08\left(x_{4 i}-6,33\right)_{+}-3,94\left(x_{4 i}-10,81\right)_{+}- \\
& 2,41 x_{5 i}-4,14\left(x_{5 i}-42\right)_{+}+8,18\left(x_{5 i}-42,75\right)_{+}-2,31\left(x_{5 i}-52,51\right)_{+}+0,63 x_{6 i}- \\
& 8,62\left(x_{6 i}-20,33\right)_{+}+8,43\left(x_{6 i}-21,48\right)_{+}-0,89\left(x_{6 i}-36,38\right)_{+}
\end{aligned}
$$

Nilai $R^{2}$ yang dihasilkan sebesar $90,69 \%$. Asumsi IIDN (Identik, Independen, dan Distribusi Normal) residual telah terpenuhi.

\section{B. Saran}

Saran yang dapat diberikan adalah sebagai berikut.

1. Model yang diperoleh diharapkan mampu memberikan konstribusi nyata bagi pemerintah mengambil kebijakan dalam meningkatkan kesertaan KB MKJP di setiap kabupaten/kota di Jawa Timur guna mempercepat pengendalian fertilitas serta meningkatkan kesehatan ibu dan anak.

2. Pemerintah atau instansi terkait lebih memperhatikan kabupaten/kota di Jawa Timur yang memiliki persentase peserta KB aktif MKJP masih rendah. Upaya dilakukan dengan meningkatkan pengetahuan kontrasepsi MKJP baik melalui konseling atau media informasi. Kemudian meningkatkan pelayanan MKJP dengan mempersiapkan sarana dan prasarana yang memadai.

\section{DAFTAR PUSTAKA}

[1] Badan Perencanaan Pembangunan Nasional, "Evaluasi Paruh Waktu RPJMN 2015-2019," Jakarta, 2017.

[2] Badan Pusat Statistik, "Provinsi Jawa Timur Dalam Angka 2017," Surabaya, 2017.

[3] L. Asih and H. Oesman, "Faktor yang Mempengaruhi Pemakaian Kontrasepsi Jangka Panjang (MKJP)," Jakarta, 2009.

[4] I. Wulandari and I. N. Budiantara, "Analisis Faktor-faktor yang Mempengaruhi Persentase Penduduk Miskin dan Pengeluaran Perkapita Makanan di Jawa Timur Menggunakan Regresi Nonparametrik Birespon Spline," J. Sains dan Seni, pp. D30D35, 2014.

[5] B. Lestari, I. N. Budiantara, S. Sunaryo, and M. Mashuri, "Spline Smoothing for Multiresponse Nonparametric Regression Model in Case of Heteroscedasticity of Variance," J. Math. Stat., vol. 8, no. 3, pp. 377-384, 2012.

[6] N. Chamidah, I. N. Budiantara, S. Sunaryo, and I. Zain, "Disigning of Child Growth Based on Multirespon Local Polynomial Modeling," J. Math. Stat., vol. 8, no. 3, pp. 342-347, 2012.

[7] D. N.R and S. H., Analisis Regresi Terapan. Jakarta: Gramedia Pustaka Utama, 1992.

[8] I. Budiantara, "Estimator Spline Terbobot dalam Regresi Semiparametrik," Maj. Ilmu Pengetah. dan Teknol., vol. 10, pp. 103-109, 1999.

[9] I. N. Budiantara, "Penelitian Bidang Regresi Spline Menuju Terwujudnya Penelitian Statistika yang Mandiri dan Berkarakter," in Seminar Nasional FMIPA, 2011.

[10] Sugiantari, Ayuk Putri, Budiantara, I Nyoman, "Analisis FaktorFaktor yang Mempengaruhi Angka Harapan Hidup di Jawa Timur Menggunakan Regresi Semiparametrik Spline," J. Sains dan Deni Pomits, vol. 2, 2013.

[11] A. A. Fernandes, I. N. Budiantara, B. W. Otok, and Suhartono. "Reproducing Kernel Hilbert Space for Penalized Regression Multi Predictors : Case in Longitudinal Data," Int. J. Math. Anal., vol. 8, no. 40, pp. 1951-1961, 2014.

[12] I. Budiantara, "Regresi Nonparametrik Spline Truncated," ITS, Surabaya, 2017.

[13] A. Tripena and I. Budiantara, "Fourier Estimator in Nonparametric Regression," in International Conference on Natural and Applied Natural Science, 2006, pp. 2-4.

[14] A. A. Fernandes, I. N. Budiantara, B. W. Otok, and Suhartono., "Spline Estimator for Bi-Response and Multi-Predictors Nonparametric Regression Model in Case of Longitudinal Data,' J. Math. Stat., vol. 11, no. 2, pp. 61-69, 2015.

[15] S. F. Nisa' and I. Budiantara, "Analisis Survival dengan Pendekatan Multivariate Adaptive Regression SPline pada Kasus Demam Berdarah Dengue (DBD)," J. Sains dan Seni ITS, pp. D318-D323, 2012.

[16] R. L. Eubank, Nonparametric Regression and Spline Smoothing, Second Edition. New York: Taylor \& Francis, 1999.

[17] D. N. Gujarati, Basic Econometrics, 4th ed. New York: Mc Graw Hill, 2004

[18] W. Daniel, Statistik Nonparametrik Terapan (Terjemahan). Jakarta: Gramedia, 1989

[19] L. Tedjo, "Faktor-Faktor yang Mempengaruhi Pemilihan Jenis Kontrasepsi yang Digunakan pada Keluarga Miskin,” Semarang. 